\title{
Peningkatan Kesadaran Penggunaan Produk Halal di Kalangan Remaja Kota Palangka Raya
}

\author{
Increased Awareness of the Use of Halal Products among Adolescent Palangkaraya City
}

Risqika Yuliatantri
Paramawidhita ${ }^{*}$
Nurul Hikmah Kartini ${ }^{2}$
1Department of Pharmacy, Universitas
Muhammadiyah Palangkaraya,
Palangka Raya, Central Kalimantan,
Indonesia Palangkaraya,
2Department of Elementary Teacher
Education,
Muhammadiyah
Palangka Raya, Central Kalimantan,
Indonesia
Remail:
risqikayuliatantriparamawidhit
@gmail.com
Kata Kunci
Kertifikasi Halal
Kesadaran
Produk
Awalarertification
Published: March 2020

\begin{abstract}
Abstrak
Maraknya peredaran kosmetika dan makanan di masyarakat terutama di kalangan remaja milenial, apalagi didukung kemajuan teknologi yang segala sesuatu bisa diperoleh dengan menggunakan jari di handphone atau media elektronik lain. Remaja milenial dari hasil observasi kurang memperhatikan tentang kehalalan suatu produk baik makanan ataupun kosmetik. Perilaku masyarakat ketika membeli produk terkadang hanya berdasarkan orientasi terhadap produk yang disukainya. Seiring dengan akan diperlakukannya Undang-Undang Jaminan produk Halal (RUUJPH) Nomer 33, tahun 2014 yang salah satu pasalnya menyebutkan semua produk harus tersertifikasi halal, maka kesadaran halal terhadap suatu produk mutlak diperlukan. Hal ini diperkuat dengan Undang-Undang Jaminan Produk Halal (JPH) terbaru sehingga banyak Lembaga Pemeriksa Halal (LPH) sekarang bermunculan. Oleh karena itu perlu dilakukan sosialisasi kesadaran halal melalui program pengabdian kepada masyarakat. Peningkatan kesadaran halal disampaikan dalam beberapa materi yaitu pengantar sertifikasi halal, kebijakan sertifikasi terbaru, kriteria SJH, serta prinsip halal dan thoyyib dalam produk makanan dan kosmetika. Hasil pelatihan ini meningkatkan pemahaman peserta tentang kesadaran halal. Motivasi peserta remaja yang memiliki usaha industri kecil untuk melakukan sertifikasi halal terhadap produknya juga meningkat. Sehingga perlu untuk tindak lanjut dari kegiatan ini adalah proses pendampingan sertifikasi halal.
\end{abstract}

\begin{abstract}
The rise of the circulation of cosmetics and food products in the community, especially among millennial adolescents, is increasingly rife, let alone supported by advances in technology that everything can be obtained only by using a finger on a mobile keypad or other electronic media. Millennial adolescents from observations often pay less attention to the halal of a product whether it is food or cosmetics. People's behavior when buying products is sometimes only based on the orientation of the product they like. In line with the enactment of Law Number 33 of Halal Product Guarantee (RUU-JPH), 2014 which one of the articles states that all products must be halal certified, then halal awareness of a product is absolutely necessary. This is reinforced by the latest Halal Product Guarantee Act (JPH) so that many Halal Examining Institutions (LPH) are now appearing. Therefore, it is very important to conduct socialization and awareness of halal through community service programs. Increased halal awareness is conveyed in a number of materials, namely introduction to halal certification, the latest certification policy, $\mathrm{SJH}$ criteria, and halal and thoyyib principles in food and cosmetics products. The results of this training improve participants' understanding of halal awareness. The motivation of young participants who have a small industrial business to do halal certification of their products is also increasing. So that it is necessary to follow up on this activity is the process of halal certification assistance.
\end{abstract}




\section{PENDAHULUAN}

Halal telah diterima sebagai standar kualitas yang diaplikasikan pada suplai dan proses produksi suatu produk. Standar halal mencakup produk makanan, kosmetik, farmasi, dan medis (Hidayat \& Siradj, 2015). Dalam memelihara standar halal, supplier dan produsen halal harus tunduk pada ketentuan mutu halal yang diberlakukan oleh lembaga sertifikasi halal (Noordin et al., 2014). Maraknya peredaran kosmetika dan produk makanan di masyarakat terutama kalangan remaja milenial sekarang semakin marak, apalagi didukung oleh kemajuan teknologi yang segala sesuatu bisa diperoleh hanya dengan menggunakan jari di keypad handphone atau media elektronik lainnya (Ainiyah, 2018). Remaja milenial dari hasil observasi sering sekali kurang memperhatikan tentang kehalalan suatu produk baik itu makanan ataupun kosmetik. Perilaku masyarakat ketika membeli produk terkadang hanya berdasarkan orientasi terhadap produk yang disukainya (Wibowo \& Madusari, 2018).

Seiring dengan akan diperlakukannya Undang-Undang Jaminan produk Halal (RUU-JPH) Nomer 33, tahun 2014 yang salah satu pasalnya menyebutkan bahwa semua produk harus tersertifikasi halal, maka kesadaran halal terhadap suatu produk mutlak diperlukan. Hal ini diperkuat dengan Undang-Undang Jaminan Produk Halal (JPH) terbaru sehingga banyak Lembaga Pemeriksa Halal (LPH) sekarang bermunculan. Logo halal seperti yang tertera pada produk memiliki fungsi yang sangat penting bagi konsumen, diantaranya adalah konsumen muslim merasa terlindungi saat mengkonsumsi makanan, menenangkan perasaan hati dan batin konsumen, menyelamatkan jiwa dan raga konsumen dari keterpurukan memakan makanan haram, serta sebagai kepastian dan perlindungan hukum (Hasan, 2014). Adapun produk yang beredar di pasaran sekarang tidak semuanya memiliki logo halal, sehingga menimbulkan kecurigaan bahwa bahanbahannya berasal dari bahan yang haram ataupun proses pembuatannya yang tidak halal (Fadzillah et al., 2011).

Produk atau makanan yang diproduksi dalam lini dengan persyaratan halal telah dapat diterima tidak hanya oleh konsumen Muslim, tetapi juga konsumen dari agama lain (Ramlan \& Nahrowi, 2013). Bagi Muslim, makanan atau minuman yang halal berarti telah memenuhi ketentuan dalam syariat Islam, sedangkan bagi non-Muslim, produk halal merepresentasikan simbol kebersihan, kualitas dan keamanan, karena diproduksi dibawah Sistem Manajemen Mutu Halal yang Holistik (Ambali \& Bakar, 2014).

Berdasarkan uraian tentang dampak buruk dari makanan atau produk yang tidak halal tersebut, maka perlu diberikan pengetahuan dan pelatihan tentang kesadaran akan halal. Dengan demikian akan menjadi lebih teliti apabila membeli segala produk yang digunakan (Syafrida, 2016). Berdasarkan dari banyaknya uraian tentang pentingnya peningkatan kesadaran penggunaan produk halal tersebut, maka disini kami memilih berorientasi kepada remaja yang sekin maraknya menggunakan segala macam jenis makanan dan kosmetika.

\section{METODOLOGI}

Peningkatan kesadaran penggunaan produk halal ini dilaksanakan menggunakan sosialisasi dengan penyampaian beberapa materi di antaranya yaitu pengantar sertifikasi halal, kebijakan sertifikasi terbaru, kriteria SJH, serta prinsip halal dan thoyyib dalam produk makanan dan kosmetika. Selain itu kegiatan pengabdian masyarakat ini pula dilakukan secara diskusi interaktif atau pembelajaran langsung terhadap remaja yang mengikuti. Kegiatan ini dilaksanakan pada bulan September tahun 2019 di rooftop lantai lima gedung 
rektorat wilayah kampus Universitas Muhammadiyah Palangkaraya dengan sasaran kepada remaja anggota Unit Kegiatan Mahasiswa (UKM) Universitas Muhammadiyah Palangkaraya.

\section{HASIL DAN PEMBAHASAN}

Hasil pelatihan ini meningkatkan pemahaman peserta tentang kesadaran halal. Motivasi peserta remaja yang memiliki usaha industri kecil untuk melakukan sertifikasi halal terhadap produknya juga semakin meningkat. Sehingga perlu untuk tindak lanjut dari kegiatan ini adalah proses pendampingan sertifikasi halal.

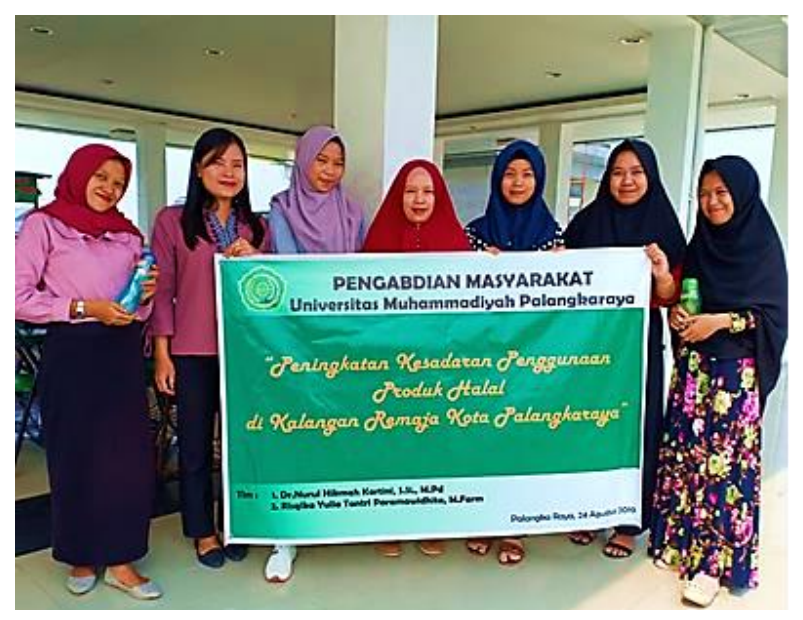

Gambar 1. Pelaksanaan Kegiatan Sosialisasi

Pengukuran hasil pencapaian kegiatan pengabdian kepada masyarakat dapat di amati dari ketercapaian tujuan dan target yang telah direncanakan. Pasca kegiatan pengabdian dilaksanakan, para remaja Kota Palangka Raya memiliki pemahaman yang lebih mendalam tentang pentingnya sertifikasi halal pada produk makanan dan kosmetika mereka. Tahap sosialisasi ini diawali dengan bentuk penyuluhan, dengan tujuan untuk melindungi masyarakat agar tidak mengkonsumsi maupun menggunakan produk yang dinyatakan haram. Terlebih sebagai umat muslim, agama islam memberikan hukum yang sangat ketat terhadap kehalalan dalam hal apapun (Sayekti, 2014). Sesuai dengan hadist RasulullahSAW yang menyatakan bahwa, "tidak akan masuk surga orang yang dagingnya tumbuh dari (makanan) yang haram, neraka lebih pantas baginya".

\section{KESIMPULAN}

Setelah dilakukan pelatihan tentang kesadaran halal, maka remaja muslim di kota Palangka Raya lebih menyadari tentang pentingnya produk halal, peserta mempunyai kesadaran bahwa produknya harus tersertifikasi halal, terampil memilih produk yang halal dan menghindari produk-produk yang tidak halal.

\section{UCAPAN TERIMA KASIH}

Ucapan terima kasih serta penghargaan sebesarbesarnya tim pelaksana pengabdian kepada masyarakat serta kepada Lembaga Penelitian dan Pengabdian kepada Masyarakat Universitas Muhammadiyah Palangkaraya yang telah mendanai kegiatan pengabdian ini.

\section{REFERENSI}

Ainiyah, N. 2018. Remaja Millenial dan Media Sosial: Media Sosial Sebagai Media Informasi Pendidikan Bagi Remaja Millenial. Jurnal Pendidikan Islam Indonesia. 2(2):221-236. https://doi.org/10.35316/jpii.v2i2.76

Ambali, A.R., Bakar, A.N. 2014. People's Awareness on Halal Foods and Products: Potential Issues for Policy-makers. Procedia - Social and Behavioral Sciences.

121:3-25. https://doi.org/10.1016/j.sbspro.2014.01.110 4

Fadzlillah, N.A., Man, Y.B.C., Jamaludin, M.A., Rahman, S.A., Al-Kahtani, H.A. 2011. Halal Food Issues from Islamic and Modern Science Perspectives. In $2^{\text {nd }}$ International Conference on Humanities, Historical and Social Sciences. 159163. Singapore: IACSIT Press. 
Hasan, K.N.S. 2014. Kepastian Hukum Sertifikasi Dan Labelisasi Halal Produk Pangan. Jurnal Dinamika Hukum. 14(2):228-238. http://dx.doi.org/10.20884/1.jdh.2014.14.2.2 92

Hidayat, A.S., Siradj, M. 2015. Sertifikasi Halal dan Sertifikasi Non Halal pada Produk Pangan Industri. Ahkam: Jurnal Ilmu Syariah. 15(2):199210. http://dx.doi.org/10.15408/ajis.v15i2.2864

Noordin, N., Noor, N.L.M., Samicho, Z. 2014. Strategic Approach to Halal Certification System: An Ecosystem Perspective. Procedia - Social and Behavioral Sciences. 121:79-95. https://doi.org/10.1016/j.sbspro.2014.01.111 0

Ramlan, Nahrowi. 2013. Sertifikasi Halal Sebagai Penerapan Etika Bisnis Islami Dalam Upaya Perlindungan Bagi Konsumen Muslim. Ahkam: Jurnal Ilmu Syariah. 14(1):145-154. http://dx.doi.org/10.15408/ajis.v14i1.1251

Sayekti, N.W. 2014. Jaminan Produk Halal Dalam Perspektif Kelembagaan. Jurnal Ekonomi dan Kebijakan Publik. 5(2):193-209. https://doi.org/10.22212/jekp.v5i2.84

Syafrida, S. 2016. Sertifikat Halal Pada Produk Makanan Dan Minuman Memberi Perlindungan Dan Kepastian Hukum Hak-Hak Konsumen Muslim. Adil: Jurnal Hukum. 7(2):159-174. https://doi.org/10.33476/ajl.v7i2.353

Wibowo, D.E., Madusari, B.D. 2018. Pengaruh Labelisasi Halal Terhadap Keputusan Pembelian Oleh Konsumen Muslim Terhadap Produk Makanan di Kota Pekalongan. Indonesian Journal of Halal. 1(1):73-80. https://doi.org/10.14710/halal.v1i1.3400 